\title{
Texts of Literary Genres in Sasak Language: Preparation of Basic Materials for Local Contents in Sasak Language
}

\author{
Khairul Paridi* \\ PBSI Study Program \\ FKIP, University of Mataram \\ Mataram, Indonesia \\ khairul_paridi@Unram.ac.id \\ S Syabuddin \\ PBSI Study Program \\ FKIP, University of Mataram \\ Mataram, Indonesia
}

\author{
I Nyoman Sudika \\ PBSI Study Program \\ FKIP, University of Mataram \\ Mataram, Indonesia
}

\author{
S Sukri \\ PBSI Study Program \\ FKIP, University of Mataram \\ Mataram, Indonesia
}

\author{
A Asyhar \\ PBSI Study Program \\ FKIP, University of Mataram \\ Mataram, Indonesia
}

\begin{abstract}
This article examines the text structure of literary genres in Sasak language, the shape of the linguistic devices and the values that are held in them. The method used is "listening method" in which the researchers record oral data and transcribed them into written texts. The transcripts were analysed using linguistic tools for identifying coherence and values contained in both oral and written texts. The results show that the structure of literary genre text in Sasak Language consists of orientations, complications, resolutions, and ending or coda, Generally, the language features can be seen in the use of references papuq 'grandparents', the use of third-person pronouns such as ie 'he/she' iepade 'they/them', in the lexical cohesion such as the use of repetition style, namely repeating words like the use of subordinate conjunctions seq uah 'after' and seq ndeqman 'before', the use of prepositions joq gawe 'to ceremonial events', the use of adverb of time and place such as leq kemalem 'in the night' and leq sopok dese 'in a village'. Texts of literary genres in Sasak language contain social, cultural, religious, and tolerance values.
\end{abstract}

Keywords-- Literary genre text, raw materials, local contents, Sasak Language

\section{INTRODUCTION}

The existence of literary genre texts in Sasak society, has been mostly passed down from generation to generation through storytelling. Therefore, in terms of quantity, the Sasak literary texts are mostly in the oral form. They contain mostly about histories of the origins of places, customs, and cultures of the society. Main characters in the folklores are usually depicted as animals, humans, or gods.

Literary texts convey their entertainment role and value-education role through the language therein and, as language-mediated entities, texts play out their functions with two types of devices. Cohesive devices regulate relationship among meanings and these are mostly performed through conjunctions, pronouns, and other cohesive devices. Coherent devices maintain logical relevance among meanings.

Based on initial observation of literature in the field, we can see that the discussion on literary genre texts in terms of structural and linguistic devices is still lacking. When research conducted by students in undergraduate theses are concerned, the studies are still limited to the problems on intrinsic elements and extrinsic elements. There has been no specific discussion about the structure and linguistics devices used in literary texts. If this problem is not adequately studied, a problem will arise that learners will have difficulties in determining the structures of texts, in achieving knowledge and skills to use linguistic devices, and in understanding the values contained in literature.

Based on the points stated above, the problems having been analyzed in this research were the text structure of the literary genre in Sasak language, the forms of the linguistic devices in the literary texts in Sasak language, and the values that are held in the Sasak literary texts.

The theory used in this research is concerned with the notion of text and discourse put forward by Halliday et al. [1]. The types and the structures of texts are based on the views of Brown and Yule (1983: 128) [2], Knapp and Megan in Mahsun (2013:19) [3] in addition to those in Halliday et al. [1], and Semi (2003: 31) [4]. Meanwhile, the notions of cohesion and coherence refer to the theories put forward by Gutwinsky and Van de Velde in Tarigan (2009: 93) [1] and theories on the suitability of language forms to context from Wohl in Tarigan (2009: 100) and Teun A. Van Dijk in Eriyanto (2001: 242 242). In the Sasak language, there are means of cohesion between sentences such as agen, adeq- $n$, ade- $n$, (so that), kanjeq (that) mun, lamun, (if) (Paridi et al., 2019: 34) [1]. The study of values is modelled on Lubis [5].

\section{METHODS}

The data were obtained from various resources ranging from Sasak language textbooks, internet media, and recordings of Sasak people who have mastered Sasak folklores and served as leading feagures in Sasak tradition. The method used to collect the data is "listening method" (Sudaryanto, 1988: 2). This technique is used to observe the use of figure of speech in the literary text of the Sasak language. In practice, observation method is carried out with recording and transcribing techniques in which the researcher recorded and transcribed the data in the form of text, analyzing the use of the figure of speech and coherency of the literary texts, analyzing the values contained in the text from both written and oral sources. The recording technique was done by using the advanced technique of "Speaking Free with Proficient Involvement" (SBLC) which was supported by note-taking. As for the oral data, literary texts were recorded using a tape recorder. 
The results of the data analysis were then presented by using informal techniques carried out by presenting the results of the analysis using technical formulas of words and sentences [6].

\section{RESULT AND DISCUSSIONS}

The following folk stories in the Sasak language that have been collected for analysis: Putri Mandalika, Balang Kesimbar, Cilinaya, Batu Golok, Doyan Mangan, and Cupak Gurantang. In addition, there are also historical stories about the Sasak people: Gumi Lombok, Selaparang Kingdom, and Pejanggik Kingdom.

From the collection of those stories, some of them are discussed in this article and some are not, considering that the discussion of each story is too broad so that the discussion is limited to stories that are popular in the midst of society. Following the formulation of the problem, the discussion is focused on the structure of the text, a figure of speech, and the values contained in the text. The following sections discuss the structure of the story, the figure of speech in the story, and the values contained in the story text, respectively.

\section{The Structure of The Stories}

After reading and examining the text of the story, the study identified that the literary genre texts in Sasak have similar structure as other narrative texts in general. The literary genre text of the Sasak language consists of orientation, complications, resolution, and ending. The use of linguistic elements in the story are presented in the following description.

\section{Linguistics Elements in The Text}

The linguistics elements used in the story which serve as cohesive devices are discussed as follows. In the Balang Kesimbar story, the use of references such as the pronoun papuq toaq dait bain, ie, and ie pade. The use of repetition styles with repeated lexical cohesion, for example Balang Kesimbar is repeated in the next sentence. In addition, the use of conjunctions to bind propositions, the movement from one idea to the next. In the Balang Kesimbar text, the use of prepositions, for example Balang Kesimbar dateng jok gawe. Likewise, with the use of information to designate the location of the event or the time of the event, adverb of time is used, for example, leq kemalem-malem papuq pinak topat.

In the story of Putri Mandalika, the linguistics elements used are related to adverb of time such as lek jaman laek to Pante Kute Pulau Lombok arak sopoq kerajaan sak aren Tonjeng Beru [In ancient times on Kuta Beach, Lombok, there was a kingdom called Tonjeng Beru].

In Datu Pejanggik story, a referential pronoun is also found, which is realized by the pronoun used in the story which includes the first, second, and third pronoun, both singular and plural. Such as in the following quotation of the story Negeri Tonjang Beru ni teperintah isiq Raja terkenal isiq kepacuanne raja nu aren Raja Tonjang Beru bekeq seninen Dewi Seranting. iye bedoe sekeq anak nine, aren Putri Mandalika [This Tonjang Baru Kingdom was ruled by a king who was famous for his seriousness, known as Raja Tonjang Baru and his wife was Dewi Seranting. They had one daughter; her name is Putri Mandalika]. The use of ie refers to the antecedent raje which is in the preceding clause. The word ie, which refers to the antecedent raje is a form of cataphoric reference since the antecedent is to the right of or is mentioned after the beginning of the clause.

Repetition is one way to maintain a cohesive relation between sentences, for example keingesan putri Mandalike sanget terkenal langan ujung timuq sampe ujung barat Lombok ke ingesan putri terengah siq pangeran-pangeran sak leq Lombok.

The phrase keingesan putri in the data above is a form of repetition which functions to create a cohesive relationship between one sentence and another. In this case, the phrase keingesan putri in the first sentence is repeated in the next sentence without changing its function as the subject of the sentence.

The use of conjunction in this following quotation Ndekn tao mangan, ndek tao tindoq. Jarin putrid kurus gero. Selapuq dengan Tonjang Beru aseq. Kembeqne putri tolaqne? Laguk, selain rase cinte yak muni, iye kendah ngerase menanggung tanggung jawap sak belek. Which literary means 'She couldn't eat, she couldn't sleep. A skinny princess she became. Everyone felt sad. Why did the princess refuse? But, apart from pure love, she also felt a great responsibility.'

The word laguk in the above quotation is a form of conjunction between sentences that functions to connect the sentence before and the sentence after it. Semantically the word laguk expresses the opposite meaning. Thus, the word laguk that connects the previous sentence with the sentence after has the opposite meaning.

In Doyan Mangan story, there are many lexicons that indicate the adverb of time and place. For example, Araq sopoq cerite leq jaman laeq, leq jaman Gumi Lombok masihne beruwe gawah dait gunung saq benes, masih jarang manusie saq araq waktu sino. "In ancient times there was a story, in the era when Lombok was still like lush forests and mountains, there were rarely humans at that time".

The phrase Leq zaman laeq in the data above is a form of adverb expressing time of events in the text. leq sopoq jelo seuahan keliningan gumi Lombok Patih Songan langsung ngelapur tipaq Dewi Anjani, iye ngelapuran Gumi Lombok uah santer benes isiq kekayuan sak tiwok.

The phrase leq sopoq jelo in the data above is one form of using the adverb of time indicates the period when the event occurred. This aims to provide a clear timeline for the story so that readers can better understand the plot of the story.

Reiteration is a way to create a cohesive relationship. The relationship is formed by repeating a part of the sentence. The repetition aims to maintain the idea or topic being discussed. Look at the quotation from the story below.

"Dewi Anjani bedoe prajurit saq tepimpin siq patih saq arane Patih Songan. Dewi Anjani bedoe Kedit beleq saq becucuk selake, bekungkuk baje saq tejulukan Beberi."

Dewi Anjani had a soldier led by a patih named Patih Songan. Dewi Anjani had a large bird with a large beaked, steel-toed hoof which was nicknamed Beberi. 
The name of Dewi Anjani in the above quotation is repeated in the next sentence. Repeating the names of the characters in the story serves to create a cohesive relationship between the first sentence and the following sentence. Note also the following paragraph excerpt.

Bebeaq saq teanakan sine sanget isiqne ajaib, barukne sugul langsung tao ngeraos, tao lampak dait tao mangan nginem mesak. Bebeaq sine santer siqne kuat mangan, sekali mangan dua bakaq nasi dait kandokne [The child who was born was very miraculous, a newborn who could speak immediately, could walk, and could eat and drink by himself. This child eats very often, and once eats two baskets of rice and side dishes].

In this quotation, the word bebeaq is completely repeated in the next sentence. The word bebeaq functions as a subject without changing its function as the subject.

The use of conjunctions serves to assemble or bind several phrases in discourse. Thus, the transfer of ideas in the discourse becomes coherent. For example, Sekeq prajuritne siqne pinak jari pengulu arane Pengulu Alim. Sengakne mulai sepulu pasangan ne pade pinak tanaq sino jari kebon bangket taoqne pade betaletan [One of his warriors was made as the head of named Penghulu Alim. Then the ten couples started to make the land into a garden where they planted crops].

The word sengakne in the data above is a form of conjunction that functions to bind several phrases in discourse so that the movement of ideas in the discourse is more coherent. In this case, the sengakne word in the data above is included in the form of a coordinative conjunction which functions to connect two syntactic elements that have the same status, either in the form of a clause, phrase or word so that the sengakne word in the sentence functions to connect the previous sentence with the sentence in front of it.

The word sengakne in the data above is a form of subordinative conjunction that is used to connect two syntactic elements in the form of independent and subordinate clause that does not have the same status. The use of the word sengakne in the sentence is to indicate a causal relationship between the 2 clauses and marked a causal relation between them.

The linguistic elements used in the text of the Selaparang Kingdom are as follows. For example, the use of conjunctions. Conjunctions serve to assemble or bind several propositions in a discourse so that the transfer of ideas in the discourse has cohesion and coherence.

Consider the following quotation "Leq mudi kesolahan Gumi Lomboq jari gumi taoq pelesiran dunie, ternyate penoq taoq dengan pelesiran saq bersejarah leq Gumi Lombok saq rugi laloqn deqte ketaoq siq dengan Lomboq ato dengan saq leman luah Lomboq (turis). Literarily, this means "Behind the beauty of Lombok Island as a world tourist destination, it turns out that there are many historical tours on the island of Lombok which are a pity not to be known by local and foreign tourists".
The word ato in the data above is a form of correlative conjunction that states the meaning of choice and indicates a parallel structure between the phrase before and after it. Also, pay attention to the quotation below.

Asal mule Kerajaan Selaparang ndeq ne teketaoqm besaq tetu tentang penembeq angkaq ne jange araq Kerajaan Selaparang. Laguk, araq sopoq due cerite saq baun tepercayaq.

The early history of the founding of the Selaparang Kingdom is still unclear. However, there are some sources that are quite reliable.

The word Laguk in the data above is a form of conjunction between sentences that functions to connect one sentence to the next. This conjunction semantically has the meaning of contradiction. Thus, the first sentence contradicts the meaning of the next sentence.

Also, consider the following quotation:

Pelinggih penembeq $n$ dating joq Lomboq nu leq dayen gonong saq tesebut siq Bayan skiter taun 600-an ato taun ke-13 M (antare taun 1201 sampe 1300 M). pelinggih mendot dait beceramah leq to, sengakne merarik sampenganaq telu leman senine penembeq, aran: (1). Sayyid Umar, saq jari Datu Kerajaan Pujut, Kabupaten Lomboq Tengaq (2). Sayyid Amir, saq jari Datu Kerajaan Pejanggik, Kabupaten Lombok Tengaq dait (3). Syarifah Qomariah ato saq tekenal siq sebutan Dewi Anjani". [It was the first time he came to Lombok Island in North Lombok Regency which was called Bayan around the 600 s Hijriyah or the 13th century AD (between 1201 and 1300 AD). He settled and preached there, then got married, three children were born from the first wife, named: (1). Sayyid Umar, who became The King of Pujut Kingdom, Central Lombok Regency (2). Sayyid Amir, who became The King of Pejanggik Kingdom, Central Lombok Regency, and (3). Syarifah Qomariah or better known as Dewi Anjani].

The word sengakne in the data above is included in the form of a coordinative conjunction which states that an activity is continued in the next activity.

\section{The Values of The Text}

The following description is the results of the text analysis which has been based on the values within the text. The values found in the text are religious values, social values, cultural values, moral values, and historical values. These values are stated in the following discussion.

The existence of folklore, of course, is not values-free. The text of the story certainly contains values that develop in the community that owns the story. This is also the case with the texts that have developed in the life of the Sasak people on the island of Lombok. Those texts are full of values, for example social, cultural, religious, and other values. 
The values contained in the Batu Golog story, for example, the value of helping each other which can be seen in the following quotation.

Permisi Bu, apakah ada yang bisa saya bantu?" tanya Inaq Lembain pada seorang wanita yang sedang menampi beras. Di rumah ibu itu, tampak beberapa wanita sedang menumbuk padi.Ibu itu memandang sekilas pada Inaq Lembain, "Aku tidak membutuhkan bantuanmu. Sudah banyak yang membantuku," jawabnya. "Tolonglah Bu, kedua anak saya butuh makan. Ibu tak perlu membayar dengan uang, cukup dengan beras saja. Asal anak saya bisa makan, saya sudah senang," kata Inaq Lembain memohon. Ibu itu merasa iba. Ia akhirnya memberi Inaq Lembain pekerjaan, yaitu menumbuk padi. Inaq Lembain berpesan pada kedua anaknya, "Jangan ganggu Ibu ya. Ibu harus bekerja. Kalian duduk saja di sini.[Excuse me, ma'am, is there anything I can help you with?" Asked Inaq Lembain to a woman who was winnowing rice. At the mother's house, several women were pounding rice. The mother glanced at Inaq Lembain, "I don't need your help. There have been many who have helped me, "she replied. "Please, ma'am, my two children need to eat. You don't have to pay with money, you just need to pay with rice. As long as my child can eat, I am happy, "said Inaq Lembain pleading. The mother felt sorry for her. He finally gave Inaq Lembain a job. Inaq Lembain advised her two children, "Don't bother Mother, okay? Mother has to work. You guys just sit here].

Based on the quotation above, the social value contained is that basically as humans we must help each other because we are social creatures who cannot live alone. This is expressed in the above quote. Its purpose is to remind us of what life should be and should maintain mutual relations with each other as well as should help each other. Apart from the value of helping, in the story Batu Golok there is a value of responsibility which can be seen from the character Inaq Lembain in the quote below.

\footnotetext{
"Ibu... Ibu... batu ini bergerak naik. Kami takut Bu.... ’'Inaq Lembain tetap tak peduli. Ia pikir anak-anaknya hanya mencari perhatian saja. Ia terus melanjutkan pekerjaannya. "Ibu... Ibu ... tolong... kami ada di atas Bu," teriak anak-anak itu lagi. Kedua anak itu terus berteriak-teriak, namun Inaq Lembain tetap tak peduli. Lama-kelamaan, suara anak-anaknya itu semakin pelan dan menjauh. Inaq Lembain tak lagi mendengar teriakan anak-anaknya.[Mother... Mother... this stone is moving up. We are scared
}

mom.... ’Inaq Lembain still doesn't care. He thought his children were just looking for her attention. she continued her work. "Mother ... Mother ... please ... we are above you Mom," shouted the children again. The two children kept screaming, but Inaq Lembain still didn't care. Gradually, the children's voices grew lower and farther away. Inaq Lembain no longer heard the screams of her children].

Based on the quotation above, the moral value contained is that basically no matter how busy we are, as parents we should be responsible by giving good attention to the family, especially our children because children are valuable and cannot be replaced by anything. When we have lost someone, especially our flesh and blood, as in the quotation above, when the character had felt the loss, the regret followed. The thing that we have right now should be taken with a best so that there is no feeling of regret, loss, sad that follows.

As for the historical value in the story, the stone that was cut by Inaq Lembain turned into two birds. The stone fragment was split into three parts, then the three pieces of rock were thrown into three regions. The first throw of the golog stone caused a very powerful tremor in Gembong Village. The second part fell on Dasan Batu. The last stone fell in the village of Montong Teker. It can be seen in the following quotation.

"Konon kabarnya, ketiga bagian batu golog
yang terbelah itu terlempar ke tiga daerah.
Lemparan batu golog yang pertama
menyebabkan getaran yang sangat dahsyat di
Desa Gembong. Bagian kedua batu golog itu
terlempar dan jatuh di Dasan Batu. Nama ini
diberikan karena ada orang yang
menyaksikan saat batu itu jatuh. Batu yang
terakhir, terlempar ke daerah yang kemudian
dinamakan Montong Teker. Nama ini
diberikan karena bagian terakhir batu golog
ini menimbulkan suara gemuruh saat
mendarat.." It is said that the three parts of
golog rock were thrown into three regions.
The first throw of the golog stone caused a
very powerful tremor in Gembong Village.
The second part of the golog stone was
thrown and fell on Dasan Batu. This name
was given because some people watched as
the rock fell. The last stone was thrown into
an area which was later called Montong
Teker. This name was given because the last
part of the rock made a thundering sound
when it landed].

Based on the quotation above, it can be seen that the historical values from the name of place in Lombok that was named after the location in which the Batu Golog were thrown. Each of these names was given based on an event that had occurred in the story of "Batu Golog" which later became the name of the area or village, namely Desa 
Gembong, Dasan Batu, and Montong Taker. Dasan Gembong, the name of this place was given based on the events that had occurred when the stone flew and fell, someone saw the incident. As a result, the village was named Dasan Batu. The name Montong Teker, the same thing happened, when the third stone fell, the sound produced a tremendous thundering sound when it landed. The name Montong Teker (Teker means thunder), therefore, was given to the place.

The social values in Putri Mandalika's story can be seen in her politeness, friendliness, and her kind language. She has a very high social life; she respects all existing circles. Her father, The King of Tonjang Beru, was known for his wisdom and always helped his people in distress. We can see this in the quotation below.

\begin{abstract}
"Selain ramah dan sopan. Tutur bahasa Putri Mandalika juga sangat lembut. Itulah yang membuat sang putri menjadi kebanggaan para rakyatnya. Semua rakyat sangat bangga mempunyai raja yang arif dan bijaksana yang ingin membantu rakyatnya yang kesusahan. Berkat segala bantuan dari sang raja, rakyat negeri Tonjang Beru menjadi hidup makmur, aman dan sentosa." "Negeri Tonjang Beru ini diperintah oleh raja yang terkenal akan kearifan dan kebijaksanaannya Raja itu bernama raja Tonjang Beru”
\end{abstract}

[Besides being friendly and polite. Princess Mandalika's word of choice is also very kind. That is what makes the princess the pride of her people. As for her father, all the people are very proud to have a wise king who wants to help his people in distress. Thanks to all the help from the king, the people of Tonjang Beru have become prosperous, safe, and secure.

The land of Tonjang Beru was ruled by a king who was known for his wisdom. The king was named the king of Tonjang Beru].

Based on the quotation above, the social value contained is that the people love the king and his family because they are not arrogant, it is an attitude that must be nurtured and must be maintained by everyone, especially in social life. As king in Tonjang Beru he carried out his duties and obligations very well, he helped his people in distress. The implicit attitudes, behavior, and actions displayed by the royal family were very good because they always put the interests of their country and the survival of their people first.

The moral value in the story of Putri Mandalika is seen when the princess did not want to choose one of the princes who proposed to her because she was afraid of disasters. It can be seen in the following quotation.

"Wahai ayahanda dan ibunda serta semua pangeran dan rakyat negeri Tonjang Beru yang aku cintai. Hari ini aku telah menetapkan bahwa diriku untuk kaтu semua. Aku tidak dapat memilih satu diantara pangeran. Karena ini takdir yang menghendaki agar aku menjadi Nyale yang dapat kalian nikmati bersama pada bulan dan tanggal saat munculnya Nyale di permukaan laut".

[O father and mother and all the princes and people of the land of Tonjang Beru whom I love. Today I have devoted myself to all of you. I can't choose one of the princes. Because this is destiny that wants me to become a Nyale that you can enjoy together on the month and date when Nyale appears on the surface of the sea].

Based on the quotation above, the moral values contained are about living in the right way. The decision made by Putri Mandalika when she had to choose one of the kings to be her husband can be made as an example. She considered and decided to reject all proposals from the six kings for a better life. He was willing to throw himself into the sea so that there would be no wars, disasters, killings, and so on. He chose a wise decision, for the sake of a peaceful life in his time. If she took one of the kings, the other 5 kings would have felt offended by the rejection and would had surely attacked the Tonjang Beru Kingdom.

The historical value in this story is when Princess Mandalika stuck something on a rock and plunged herself into the sea. There is no sign of the princess in that place. After a while, a large number of sea creatures appeared which were now called Nyale and could be consumed as food which can be seen in the following quotation.

Tidak lama kemudian, sang putri melangkah, lalu berhenti di onggokan batu, membelakangi laut lepas. Di situ Putri Mandalika berdiri kemudian ia menoleh kepada seluruh undangannya. Sang putri berbicara singkat, penuh tanda tanya, mengumumkan keputusannya dengan suara lantang dengan berseru: 'Wahai ayahanda dan ibunda serta semua pangeran dan rakyat negeri Tonjang Beru yang aku cintai. Hari ini aku telah menetapkan bahwa diriku untuk kamu semua. Aku tidak dapat memilih satu di antara pangeran yang hadir. Karena ini takdir yang menghendaki agar aku menjadi Nyale yang dapat kalian nikmati bersama pada bulan dan tanggal saat munculnya Nyale di permukaan laut".

[Not long after, the princess took a step, then stopped at a pile of rocks, her back to the open sea. There Princess Mandalika stood then she turned down all the proposal. The princess spoke briefly, full of questions, announcing her decision in a loud voice by exclaiming: $O$ father and mother and all the princes and people of the land of Tonjang Beru whom I love. Today I have devoted myself to all of you. I could 
not choose one of the princes. Because this is destiny that wants me to become a Nyale that you can enjoy together on the month and date when Nyale appears on the surface of the sea].

Since the day Putri Mandalika threw herself into the ocean and turned into a sea creature the people of Central Lombok annually hold a tradition known as Bau Nyale. The above quotation is a sign that when the Bau Nyale tradition is to be carried out, it is usually adjusted to the date set by the traditional Sasak community known as pemanggku. This determination was made based on the history that has occurred in the story of Bau Nyale, on the 20th of the 10th month of the Rowot Sasak calendar.

Aside from the historical values described above, there is also a social value of tolerance. This can be seen in the story of Cupak Gurantang. Consider the following quotation.

"Ketika dia lapar, maka dia meminta Gurantang untuk mencari makanan, setelah makanan telah siap saji lantas kemudian mereka berdua berencana makan bersamasama. Sebelum makan, muncul sikap tamaknya si Cupak, meminta Gurantang mencari air minum dan sekembalinya Gurantang mencari air minum, makanan sudah habis dilahap dan Cupak pura-pura tertidur. Malah ketika terbangun dia menyalahkan Gurantang dan menuduhnya menghabiskan makanan itu. Akhirnya, mereka bertengkar, walaupun pada akhirnya mereka berdua menyalahkan anjing. Sebenarnya, Cupak lah yang telah menghabiskan makanan tersebu".

[When he was hungry, he asked Gurantang to look for food, after the food was ready, then they both planned to eat together. Before eating, Cupak's greedy attitude appeared, asked Gurantang to look for water and when Gurantang returned, the food had been devoured and Cupak pretended to be asleep. In fact, when he woke up, he blamed Gurantang and accused him of finishing the food. In the end, they got into a fight, even though in the end they both blamed the dog. Actually, Cupak was the one who finished the food].

The social value contained in the quotation above is about how humans, as social beings, should live their lives. Traits that are destructive and selfish should be thrown away so that it would not harm others, especially the cunning nature that exists in each individual.

The moral values contained in the story of Cupak Gurantang are seen when Cupak makes a competition or sayamabara perisean which is a typical custom of the Sasak Tribe and the reward is that if Cupak is defeated, Sekar Wangi's daughter will belong to him. Gurantang also participated in the competition and Cupak did not know about it. This can be seen in the following quotation.

"Akhirnya dia membuat kompetisi dan
menjanjikan siapa yang menang melawan dia
perisean (tradisi adat Sasak), akan
medapatkan Sekar Nitra menjadi istrinya.
Gurantang ternyata masih hidup dan
mengikuti kompetisi perisean tersebut. Nasib
selalu adil, dia pun menang dan
mendapatkan yang selama ini menjadi
haknya"
[Finally, he made a competition and promised
whoever win against him in perisean (Sasak
fighting tradition), would get Sekar Nitra to
be his wife. Gurantang was still alive and
was taking part in the competition. His fate is
always fair, he won and got what has been his
right].

The value contained in the quotation is that goodwill always be good and bad will always be bad. The good that we do will certainly be rewarded with kindness. In contrary, when we commit a crime just so that we win, we won't get the victory because we go through the path of evil. As an example, in the story of Cupak Gurantang it can be learned that basically people who have a good soul will always get good luck and goodness, of course, and people who have a bad soul then what they get is badness as well.

\section{CONCLUSION}

From the discussion described above, the following conclusions are drawn. Text in the form of a fictional story consists of orientation, complications, resolution, and ending/coda, The language elements used are generally in the form of reference to personal pronouns such as papuq 'grandparents'; there is also a third-person pronoun such as ie 'he/she' iepade 'they/them'; lexical cohesion such as the use of repetition style by repeating the word in the next sentence; use of conjunctions such as sequah 'after' seqndeqman 'before' nyengke 'being'; use of prepositions, for example jok gawe 'to a ceremony'; use of adverbs of time and place, for example, leq kemalem 'at night' leq sopoq dese 'in a village'. They values contained in the literary text genre are in the forms of social values, cultural values, religious values, and tolerance values.

\section{REFERENCES}

G. Yule et al., Discourse analysis, vol. 2, no. 9. Routledge, 2014 G. Brown, G. D. Brown, G. R. Brown, B. Gillian, and G. Yule, Discourse analysis. Cambridge university press, 1983.

[3] Mahsun, Teks dalam Pembelajaran Bahasa Indonesia. Jakarta: Rajawali Press, 2013.

[4] A. Semi, Seni Budaya. Jakarta: Gramedia Pustaka Utama, 2001.

[5] A. H. H. Lubis, Analisis Wacana Pragmatik. Bandung: Angkasa Pura, 1991.

[6] Sudaryanto, Metode Linguistik. Yogyakarta: Gajah Mada University Press, 1988. 